\title{
The Quest for Election and State of Emergency in Ethiopia: An Appraisal on Related Constitutional Issues in Focus
}

\author{
Zelalem K. Bekele \\ College of Law and Governance Studies, School of Law, Dilla University, Dilla, Ethiopia \\ Email: zolabekele@gmail.com
}

How to cite this paper: Bekele, Z. K. (2020). The Quest for Election and State of Emergency in Ethiopia: An Appraisal on Related Constitutional Issues in Focus. Beijing Law Review, 11, 947-962. https://doi.org/10.4236/blr.2020.114056

Received: November 15, 2020

Accepted: December 15, 2020

Published: December 18, 2020

Copyright (๑) 2020 by author(s) and Scientific Research Publishing Inc. This work is licensed under the Creative Commons Attribution International License (CC BY 4.0).

http://creativecommons.org/licenses/by/4.0/

\section{(c) (i) Open Access}

\begin{abstract}
Ethiopia has been sharing the evils and vices of COVID_19, which is the deadly viral pandemic and spreading across the world without any territorial restriction. Almost every nation-state has got started responding to prevent it so as it has become highly preventive to discover its curative medicine, even vaccine till now. Accordingly, Ethiopia has enacted an emergency decree in order to ignite the possible preventive measures, amid, prohibition of mass gathering, stay-at-home, physical distancing, discontinuing any face to face teaching-learning process, etc. Due to this fact, the upcoming national election has been postponed under such elements of surprise that the election process can pay the way for further communicability of this pandemic and result the worst scenarios instead of its worthiness. This makes the sixth election period that has to be conducted every five years to get additional time of extension, which has initiated Constitution issues of how to do so i.e. the question of reason and time together. Besides, the office term of the House of People Representatives (HoPR) is also put under question by superseding it what would be the fate of the country after expiry of the parliament office since there is no room in the Constitution to extend its office term. Thus, this article is meant to analyze the appropriateness of the options put forward by the government, i.e. the dissolution of HoPR, constitutional interpretation, amendment and emergency declaration over election with other collateral issues under consideration. In doing so, strict digest of universal norms, constitutional principles and jurisprudential point of view of the state of emergency have been consulted. Aftermath, it aims to reveal the common ground for mutual consensus amicably. Finally, it has come up with emergency decree that should be the governing law with the point of no reservation once it is declared under an element of legitimate situation.
\end{abstract}




\section{Keywords}

COVID-19, Election, HoPR, Constitutional Issues, Emergency Declaration

\section{Prolegomenon}

Covid-19 has already been widely spreading to most countries around the world and in all African countries at continental level. ${ }^{1}$ Most nation states have adopted measures to tackle the spread of the pandemic, and some of them have promulgated states of emergency. Other measures range from social distancing to bans on mass gatherings, stay-at-home orders, using face mask, total or partial lock-downs and the likes are put in place to mitigate or avoid the contagion rate of the pandemic. Most of these measures have an impact on people's enjoyment of their human and democratic rights, including on the right to vote and on the organization of timely and credible elections. National elections, either presidential or parliamentary, local elections as well are rescheduled to post overcoming this pandemic in several countries across the world and could face various challenges posed by the sprouting pandemic situation. ${ }^{2}$ By the same token, nothing is exceptional for Ethiopia, too.

Conducting an election in normal parlance times is critical building protuberances for societies and a test for leveling the status of democracy in practice with significant resources demanded in terms of time, finance and human resource. Voters, candidates, observers and electoral officials are all engaged as the fore fronters in the electoral process highly and mandatorily. More often than not, electoral periods have been spoiled by human rights violations undermining the holding of credible and fair elections. The Covid-19 pandemic poses an additional challenge to electoral processes and raises concerns for the holding of free, fair, transparent and peaceful elections, all while ensuring the safety of citizens. With the ubiquitous threat of the pandemic, states are now being forced to assess whether they are in a position to hold free and fair elections, a component of democratic governance, and further of peace, security and development unreservedly.

Emergency declaration happens, thus, the governing law at the time when ordinary laws could not fit so as what is to be regulated is extra-ordinary beyond board during this time undoubtedly. Put differently, operating traditional institutions and laws do not serve the purpose. That is why the emergency decree clause appears in the supreme law of the land the Constitution in order to overcome unexpected exigency situations potentially. For this purpose,

${ }^{1}$ Worldometer, available at: https://www.worldometers.info/coronavirus/\#countries, visited on 28 September 2020.

${ }^{2}$ What happens after elections are postponed? Responses to postponing elections during COVID-19 vary by regime type, available at:

https://www.idea.int/news-media/news/what-happens-after-elections-are-postponed-responses-pos tponing-elections-during visited on 30 September 2020. 
the FDRE Constitution has enshrined the substantive and procedural elements of emergency decree accordingly. ${ }^{3}$ Within the purview of this content of the Constitution, the Ethiopian government passes emergency declaration to combat COVID-19, which is communicable, including zoonotically, and deadly viral pandemic disease.

Coincidentally, as the matter of fact, the decree has been passed for five months up to September ${ }^{4}$ though there is an upcoming national election to be held in August but postponed due to this exigency situation. Due to the postponement of the election, the controversy has been ignited by the politicians and scholars of different fields. The contention appears bitter and arduous by its referral to the Constitution. In the due course, some scholars and politicians have been intensifying the tension by subscribing to their opinion that the government has a prior plan to postpone election period and this incident could not be a justification to extend the election period. So, undergoing the election is mandatory and with no option to this end according to them.

Expectably, there is a counter claim to this argument by the government and its comrades, some politicians and scholars. Subscribing to their argument different counter points, they disclaimed the side of their opponent that the election must be postponed since election requires multitude activities that can escalate wide spreading of the pandemic like through recalling mass gathering, movement of people from place to place, inter alia, which are strictly prohibited by the emergency decree. ${ }^{5}$ According to them, conducting election is disastrous during this time and goes against the utmost overwhelming public interest too. To this end, though there is no way to postpone an election as well as parliamentary office term within the current setting of the Constitution straightforwardly; the government has come up with four constitutional options, which are dissolving the House of People Representatives, amending the Constitution, interpreting the Constitution and staying under emergency declaration alternatively. Thus, this article aims to digest and suggest which of these options could be genuine and plausible to tackle the problems on its face. Henceforth, it provides the possible accommodative option among them with reasonable justifications objectively. In doing so, the writer has undertaken series of looking in to the matter under consideration from international and regional laws. Furthermore, constitutional legal digest has been made to demonstrate the gap between the current practice and the Constitution in force by taking in to account the jurisprudential view on the issues as well.

Therefore, the article discusses the essence of the state of emergency firstly.

${ }^{3}$ The Constitution of the Federal Democratic Republic of Ethiopia, Proclamation No. 1/1995, Federal Negarit Gazeta-No.1, $21^{\text {st }}$ August 1995, article 93.

${ }^{4}$ Ethiopian State of Emergency Proclamation Enacted to Counter and Control the Spread of COVID-19 and Mitigate Its Impact, Proclamation No. 3/2020, article 8.

${ }^{5}$ Following the Proclamation No. 3/2020, Regulation enacted by Council of Ministers enlisted the restrictions under article $3(1)$, available at:

https://globalfreedomofexpression.columbia.edu/publications/ethiopian-council-of-ministers-regul ation-for-the-implementation-of-the-state-of-emergency/, visited on 25 May 2020. 
Secondly, it addresses the place of emergency decree in regional and international law. Finally, it puts forward the legal digest on Ethiopian laws towards summary lastly.

\section{A Circle of Basic Concept of State of Emergency}

Emergency declaration has an exceptional loin share in constitutional practice and theory (David Dyzenhaus, 2006). To be specific, state of emergency is a special legal regime regulating activities of public administration and local self-government bodies, legal entities (irrespective of their legal form) and their officials, which is expected to be declared according to the National Constitution. A comparison of the constitutional orders reveals that they have to choose between seeking to entrench in a written Constitution, if they have one, rules about how the state may respond to an emergency and leaving such responses to be decided as and when an emergency occurs. There may not be pre-prepared legal and institutional frameworks beforehand that what matters is the nature and characteristics of the factor that demands an emergency decree. For instance, the US Constitution contains only one clear constitutional prescription for emergencies under article 1 (9); stating that the privilege of the Writ of Habeas Corpus shall not be suspended except when Rebellion or Invasion of the public Safety requires it (Tor Ekeland, 2005) (Emphasis added). In striking contrast, the German Constitution contains a detailed, not exhaustive, set of prescriptions for the federal authority's response to an emergency. ${ }^{6}$

If the first choice is made, there has to be another choice between two models of emergency power:

1) The executive model, which delegates to the executive the authority to decide on whether there is an emergency and how best to respond to the emergency and

2) The legislative model, which requires the legislature to design a legal regime that deals with both of these issues.

Either of them is chosen, there has to be yet another choice about the extent to which judicial supervision is part of the emergency regime. Indeed, if judicial supervision is given a very large role, one might take into account an emerging third basic constitutional model for emergencies the judicial model. The latter two choices have to be made even when a legal order does not have a constitutionally entrenched emergency regime, whether because there is a minimal or no attempt within the written Constitution to regulate emergencies or because the legal order has opted not to have a written Constitution. ${ }^{7}$

Of course, it does not follow from the fact that a legal order has no written Constitution that it is not a constitutional order. Within the common law tradition arguments are made that the unwritten Constitution is a source of prin-

${ }^{6}$ Basic Law for the Federal Republic of Germany in the revised version published in the Federal Law Gazette Part III, classification number 100-1, as last amended by Article 1 of the Act of 28 March 2019 (Federal Law Gazette I, p. 404), article 81.

${ }^{7}$ Ibid, p. 443. 
ciples for regulating emergencies. These principles are given expression by judges in the course of deciding particular cases, so that their main manifestation is in judicial decisions. Similar arguments can be made that the principles of a written Constitution, often again as interpreted by judges, govern emergencies even if the Constitution does not explicitly contain this view though it is being done by the House of Federation in Ethiopia, which is none judicial and quasi-judicial organ. It is even arguable that the very commitment to constitutionalism shapes the choice of model so that the constitutional regulation of emergencies will take that shape no matter what an actual written Constitution stipulates.

The premise of this argument is that all legal orders have one constitutional feature in common, no matter how much they differ in other respects. They are committed to a principle of legality, which in written Constitutions will be given different kinds of concrete expression. Nevertheless, the content of that principle is not exhausted by such concrete expression since the principle has to be presupposed in order for these orders to be such to be legal orders. It is this last argument that gets closer to the point of considering why states of emergency may play an inimitable role in the constitutional discourses. However, a full appreciation of this possible role for states of emergency to shed light on constitutionalism requires one more step. There is a need to take into account the counter-argument that actual emergency practice in any constitutional order will reveal the limits of constitutionalism, even and more dramatically that such practice shows the emptiness of the liberal constitutional project, by which the author means the constitutional commitment to put in place the rule of law rather than the arbitrary rule of men. To be specific, states of emergency might be thought to show the impossibility of constitutionalism succinctly. And, thus, an inquiry into what states of emergency reveal about constitutionalism cannot remain at the level of comparative design and practice; it has to engage with profound questions of legal and political theory.

The archetypal transcript remains John Locke's Second Treatise of Government in this regard (John Locke, 1980). Locke inscribed the virtues of the rule of law of the merits to liberty of life under "settled standing" legislated rules common to all in contrast to "the inconstant, uncertain, unknown, arbitrary will of another man" (Ibid, paras 22 and 137). Nonetheless, he also insisted that in emergencies the government had to have a prerogative or legally unconstrained power to "act according to discretion, for the public good, without the prescription of the Law and, sometimes, even against it" (Id. para 160). Locke is, thus, responsible within the liberal tradition for the view that an emergency is ungovernable by the legal regime in place for regulating normal life since an effective response to an emergency may require that some state institutions respond quickly and effectively to threats either without legal authority or even against the law. Lockeans regard it as clear that neither the legislature nor the judiciary is capable of the swift, energetic action required to deal with an emergency, which leaves the executive by default as the authoritative body. However, they 
also suppose that that such a response can be on liberal terms since the executive should be guided by the supreme law of nature the safety of the people (Id. chapters XIII and XIV, p. 444).

In the $12^{\text {th }}$ century, Locke's idea was radicalized by Carl Schmitt, in the opening line of Political Theology: "Sovereign is he who decides on the state of exception" (Carl Schmitt, 2005). Schmitt also supposes that in extra-ordinary times the sovereign is legally uncontrolled. Nonetheless, Schmitt's thought goes further. Not only is the sovereign legally uncontrolled in the state of emergency, he who is the sovereign is revealed in the response to the question of who gets to decide that there is an emergency such that declaring state of emergency is appropriate.

Schmitt's position presupposes that sovereignty is a pre-legal idea; the sovereign's authority is not constituted by law ultimately. It resides in a political discourse, not in a legal Constitution. Closely bound up with Schmitt's claim about states of emergency is another claim about "the politics" (Carl Schmitt, 1976). According to Schmitt, the politics is prior to law and its central distinction is between friend and foe, so that the primary task of the sovereign is to make that distinction. It is in the moment of the emergency that the existential nature of the politics is demonstrated. Since to make that distinction is to make a kind of existential decision, he who makes it has to be capable of acting in a decisive way, which for Schmitt, as for Locke, ruled out both the judiciary and parliament, leaving the executive as the only serious candidate (Carl Schmitt, 1985). However, it follows for Schmitt that even when liberals recognize the problem that a state of emergency is a state of exception to regular norms and principles, they do not have the theoretical or practical resources to cope with that problem. The state of emergency is "something incommensurable to John Locke's doctrine of the constitutional state" (John Locke, 1980).

Because of this incommensurability, Schmitt thought that liberal theorists and liberal states will and should discard the idea that a legally uncontrolled executive has authority not only to respond to an emergency, but also to decide that there is an emergency. Such a refusal, in his view, characterized the neo-Kantian legal theory elaborated by Hans Kelsen $12^{\text {th }}$ century. Nevertheless, the consequence of that refusal is that protections for individual liberty associated with the rule of law become ever more attenuated until the point where the rule of law is said to exist as long as the executive can claim that it has a valid or purely formal authorization for its actions.

In other words, the liberal reverie of the constitutional state in which public coercive judgments are made by a centralized legislature and put into laws of general application deteriorates inevitably into the nightmare of the administrative state, in which such judgments are made by the decision of particular officials at the point of application of the laws. But what is applied is neither the law nor something authentically public. Rather, an exercise of arbitrary power by a particular official legitimized by a legal theory evacuated of all liberal substance 
reduced to an empty proceduralism: the rule of law is reduced to a regime of delegations of authority in which the constraints are purely formal.

It does not then matter much, even at all, to Schmitt whether liberals adopt the Kantian, principled stance that the rule of law can and should control politics, even in times of great political stress or the more pragmatic, Lockean liberal stance that the liberal state has to respond in such times outside of the law. For the Kantians content themselves with law's form, permitting liberalism's enemies to capture politics from within, whereas the Lockeans give to liberalism's enemies the license to capture politics by using extra-legal methods (Fionnuala Ní Aoláin, 2006).

Schmitt is and has to be taken seriously because the claim that the executive is the real agent in responding to emergencies seems to have considerable support in legal and political experience. Usually, this claim is put on a practical basis_ only the executive branch has the information and the capacity to act quickly and decisively in response to an emergency. But that pragmatic basis is always combined by implication if not explicitly with a normative one. Here "ought" seems to follow from "is". Since only the executive is capable of the kind of decision required to respond effectively to an emergency, the constitutional authority that inheres in every legal order to declare and react to the state of emergency belongs to the executive. At most, the legal order can inscribe in its Constitution, its recognition that the executive has the constitutional authority to decide both when there is an emergency and how to respond to it. For instance, article 16 of the 1958 French Constitution, which has been described as one of the "broadest grants of emergency powers to the executive in a modern Constitution" (Jenny S. Martinez, 2005/6). Article 16 gives the President unilateral authority to declare an emergency when the institutions of the Republic, the independence of the Nation, the integrity of its territory or the fulfillment of its international commitments are under serious and immediate threat, and when the proper functioning of the constitutional public powers is interrupted. The President decides both that there is an emergency and how to respond to it. Article 16 does set out some conditions. It stipulates that the measures "must stem from the desire to provide the constitutional public authorities, in the shortest possible time, with the means to carry out their duties" and it requires both that "Parliament shall convene as of right" and that the National Assembly shall not be dissolved during the exercise of the emergency powers. In addition, the President has to consult the Constitutional Council with regard to the measures. To end with, a 2008 amendment requires the Constitutional Council to give its opinion after 60 days as to whether the emergency conditions persist. The President is not, however, bound to adopt the opinion of any other institution, though article 68 permits Parliament to impeach the President for a "breach of his duties patently incompatible with his continuing in office". Thus, the possibility exists of a formal legal sanction, likely triggered by the fact that other public institutions continue their operation and are given the opportunity to express public disagreement with the 
President. However, there are no internal, enforceable checks on the President's authority. ${ }^{8}$

Additionally, it is also possible to mull over that Bruce Ackerman's assertion, a leading US constitutional theorist who argued in the wake of 9/11 that legal controls are impractical in a time of emergency, in part because judges always defer to the executive during such a time. As a result, he sketched an elaborate scheme of political safeguards to control the executive rather than legal ones. Yet Ackerman too surrendered to the pull of the rule of law by making it an essential component of his model for dealing with emergencies that these safeguards be either put into a written Constitution or subordinate laws, so that their observance would be reviewable by judges (Bruce Ackerman, 2006).

In order to demonstrate, some further examples of constitutional design and constitutional practice that will show the basis for the Schmittean view of states of emergency and their implications for constitutionalism; it is important to note that the complications of this issue go far beyond states of emergency, a phenomenon of which lawyers and political scientists in the US are well aware as they seek to deal with the way in which the office of the president and the executive in general seem increasingly free of constitutional and legal constraints. ${ }^{9}$ However, the examples hardly tell unambiguously in favor of Schmitt. Indeed, they might serve to show that the constitutional choice is not between various institutions_ the executive, the legislature and the judiciary_ but between an empty-headed or merely procedural account of legality and one that links procedure to substance. Furthermore, the latter requires that all three powers work

\footnotetext{
${ }^{8}$ Article 36 of the French Constitution sets out another model for dealing with emergencies, the "state of siege". The Council of Ministers, led by the President, has the authority to declare a state of siege for up to 12 days; any further extension has to be approved by the Parliament. The state of siege basically involves the transfer of powers ordinarily exercised by civilian authorities to the military but it is also regulated by legislation, which diminishes the extent of executive authority under it. See William Feldman (2005), Theories of Emergency Powers: A Comparative Analysis of American Martial Law and the French State of Siege, 38 Cornell International Law Journal 1021, p. 1028-9.

${ }^{9} \mathrm{~A}$ full appreciation of this point can be found in recent work by Adrian Vermeule, who follows Schmitt in arguing that the executive is as a matter of fact uncontrollable by legal norms both when it comes to emergency decisions and the ordinary day-to-day decisions taken by the officials, who staff the administrative state; Adrian Vermeule (2008/9), Our Schmittian Administrative Law, 122 Harvard Law Review 1095. As he reflects on it, on Schmitt's view, liberals should not fear that the lack of legal constraint in emergency times will spill over into ordinary times; rather, there is a 'type of reverse spillover, from ordinary to extraordinary times' in any complex administrative state. Moreover, taking his cue from Schmitt, Vermeule thinks it is normatively desirable that the US president be legally unconstrained when it comes to emergency decisions. See, also Eric A. Posner and Adrian Vermeule (2007), Terror in the Balance: Security, Liberty and the Courts. Nonetheless, his reasons for thinking so is not that such lack of constraint enables the distinction between friend and foe to be made in a way that will establish the substantive homogeneity of the people. Rather, he supposes that the kind of cost-benefit analysis associated with a laissez-faire picture of society argues for the efficiency of leaving such decisions to the President. And, it seems, the question of the extent to which the officials of the administrative state should have their legally uncontrolled powers is also to be settled on efficiency grounds. The difference between him and Schmitt is that Vermeule is confident that a highly individualistic society can sustain itself even in the face of existential threats, given that the kind of legally uncontrolled decision that has to be made to deal with such threats is a fact of life in extra-ordinary or ordinary times indifferently.
} 
together in ensuring that responses to emergencies accord with constitutional principles.

\section{What Do International and Regional Laws Provide about Election during State of Emergency?}

Fairness, transparency and freedom are the characteristics of credible elections. The pacific conduct of elections has also come to be considered as an intrinsic essential of democratic elections. The COVID-19 crisis has come up with one more additional ingredient to the holding of democratic elections, which diminishes the safe and secure nature of the elections, with relation to the health of the partakers. The principles of fair, transparent, free, peaceful and safe elections are enshrined in several international and regional legal documents. For instance, the African Charter on Democracy, Elections and Governance (ACDEG) recognizes the importance of consolidating a culture of political change based on the regular undergoing of transparent, free and fair elections held by national, independent, competent and impartial electoral bodies. ${ }^{10}$ Conducting peaceful, transparent, free, and fair elections organized by independent institutions is one of the foundations of any rule of law and peaceful political life, not to mention a country's development. Genuine democratic elections require an environment promising to respect of human rights and fundamental freedoms, including freedom of peaceful assembly and association, freedom of opinion and expression and personal security and safety, all of which are crucial elements for the effective exercise of the right to vote. ${ }^{11}$

The International Covenant on Civil and Political Rights (ICCPR) refers to the right of every citizen to take part in the conduct of public affairs and to the right to vote in elections "guaranteeing the free expression of the will of the electors". ${ }^{12}$

The Southern African Development Community (SADC) have developed some Principles and Guidelines governing democratic elections, particularly introduced by the Declaration on the Principles Governing Democratic Elections in Africa of the OAU, which list, amid, the following principles for conducting of democratic elections: ${ }^{13}$

- Full participation of the citizens in the political process;

- Freedom of association;

- Regular intervals for elections as provided for by the respective National Constitutions;

\footnotetext{
${ }^{10}$ African Charter on Democracy, Elections and Governance (2007), article 3 and 7, available at: http://archive.ipu.org/idd-E/afr charter.pdf, visited on 27 May 2020.

${ }^{11}$ Supra note 3 , article 38 .

${ }^{12}$ ICCPR (1966), Adopted by the UN General Assembly in resolution 2200 A (XXI) of 16 December 1966 at New York, entered into force on 23 March 1976, article 25.

${ }^{13}$ African Union Declaration on the Principles Governing Democratic Elections in Africa, AHG/Decl.1 (XXXVIII) (2002), article 4, available at:

https://www.ohchr.org/EN/Issues/RuleOfLaw/CompilationDemocracy/Pages/AHG.aspx, visited on 23 May 2020.
} 
- Equal opportunity to exercise the right to vote and be voted for and

- Voter education.

The SADC Principles and Guidelines also mentioned the responsibility of the State to "ensure that adequate security is provided to the entire electoral process including all political parties participating in elections". ${ }^{14}$ Further, the ACDEG also puts forward that "State Parties shall create a conducive environment for independent and impartial national monitoring or observation mechanisms". ${ }^{15}$ A conducive environment for free, fair and peaceful elections is also part of the guidelines for the observation of elections developed by the SADC, along with a "timeous announcement of the election date". However, in times of public emergency, derogations and limitations to certain human rights and electoral obligations, including voting processes, may be permitted, based on the exceptional nature of the context and subject to strict conditions, saving therein, however, the right to elect and to be elected cannot do absolute. It could be suspended under absolute exigency circumstance of the current one. At this point, it is worthwhile to take in to account the United Nations (Center for Human Rights) stipulation in this regard, "postponement of scheduled elections necessitated by public emergency may be permitted in certain limited circumstances, but only if and to the extent strictly required by the exigencies of the situation. Any such exigencies must comply with all the rigid international standards for such derogations and must not threaten democracy itself. Indeed, the UDHR itself proclaims that any limitations on the rights and freedoms contained therein must be for the purpose of "meeting the just requirements of morality, public order and general welfare in a democratic society." Accordingly, the interruption of periodicity will, in all but the most exceptional circumstances, violate international standards." ${ }^{16}$ Therefore, it goes without saying to extend election period due to the nature and characteristics of the current global pandemic COVID-19 under element of surprise.

\section{Contingent Constitutional Issues and Emergency Decree: Where the Right Went Wrong?}

Ethiopia is under state of emergency due to the pandemic COVID-19 as of April 2020. The emergency decree contains numerous restrictions like mass gathering, stay-at-home, self-quarantine, compulsory quarantine, prohibition against assembly, physical distancing etc. This being so, as a matter of coincidence, those restrictions will happen to be the challenges to the upcoming election to be held in August 2020. Nevertheless, the restrictions are among crucial measures to combat this deadly pandemic undoubtedly. At the same time, conducting election is with no option and a month before the current parliament office term has

\footnotetext{
${ }^{14}$ Supra note 10 .

${ }^{15}$ Supra note 13 , article 22.

${ }^{16}$ Election obligations and data base (EOE), available at:

https://eos.cartercenter.org/quotes?part\%5B\%5D=6 visited on 24 May 2020.
} 
been expired, the regular election must be carried out every five years. ${ }^{17}$ For one thing, how to extend the office term of the House of People Representatives is not provided that reproaching the Constitution in this way entails null and void. On the other, postponement of election gets the same thing that no stipulation to govern the matter under consideration is enshrined under the Constitution too in plain language.

However, as far as election is concerned, it is possible to substantiate the following powerful constitutional arguments additionally that support the conclusion that the election during state of emergency could be invalid from a substantive point of view. Firstly, the compulsory quarantine (demanded by law in critical cases) or reasonable self-quarantine of voters (advised by the government in many cases) directly limits the constitutional right to vote. This limitation cannot be remedied in any manner. May it be a redressal at least; there is no electronic voting system in Ethiopia, even for people with disability. Had it been implanted itself; it is highly preventive to practice and time taking to introduce it by now overnight so much so that majority of the people are illiterate, living in countryside where there is no access at all, no possibility to avail it for them as well and too far from such technological means of deployment (no know how and it is sole ideal that no way to tackle or overcome it at this time). For the right to vote, however, it must be effective and a mass limitation of this right should be taken into account when assessing the validity of certain election. ${ }^{18}$

Secondly, the restrictions because of the pandemic also limit the constitutional right to stand as a candidate under equal conditions. Under the COVID-19 proclamation and regulation restrictions, the candidates cannot run their campaigns in a normal way in equal footing. ${ }^{19}$ Therefore, one of the fundamental democratic rules cannot be safeguarded (the majority rule). As has been known, the full understanding of the majority rule needs an equality element (equality of political opportunity). This element is lost in Ethiopia now as a consequence of extra-legal measures provided by the special laws on fighting the pandemic.

Thirdly, according to the well-established constitutional principles, the election must be accompanied by strong guarantees of the freedom of expression, including the voters' freedom from fear against expressing their political preferences. It means that a reasonable threat to voters' health and lives, like this pandemic, should also be taken into consideration. The liberal democratic state cannot demand a heroic attitude of voters toward elections. Last but not least, voters cannot be burdened with a constitutional obligation to secure peaceful and safe elections. It is the public authorities' job to shoulder this risky business. Besides, there is no reservation for human and democratic rights including the right to vote except those provided under article 93 (4) (C) of the

\footnotetext{
${ }^{17}$ Supra note 3 , article 58 (3).

${ }^{18}$ Supra note 13 .

${ }^{19}$ Supra note 5 . Look in to the sub articles provided under article 3 of the regulation and grasp out the prerogative of the executive in power by now easily. Except the officials of the ruling party, it is a daunting task to undertake campaign and the like for the opposing parties.
} 
Constitution. ${ }^{20}$ Thus, it is possible to reach at the conclusion safely that it highly preventive and impractical to conduct resonant and up to standard election during the time of exigency situation due to the pandemic. And the postponement of election is valid and legitimate objectively.

This being taken affirmatively; it is at this juncture that the government has come up with four options for the resolution. Dissolution of the House of People Representative, constitutional interpretation, constitutional amendment and continuance with emergency decree are put forward to choose one of them under the choice of evil theorem; to choose the lesser evil though all of them are not appropriate had it not been to attain the greatest good by saving life and health of the public at large. Put differently, opting for election may lead towards irreversible cost of life of people in hundred thousands, even more according to the current anticipation. To begin with deliberation on the alternatives, except executing the emergency decree, there is no room to deal with the remaining three options during the time of emergency declaration. Under FDRE Constitution, the provisions governing those matters are supposed to be deactivated under element of surprise of emergency decree. During such extra ordinary situation except provisions made non-derogable under article 93 of the Constitution, the remaining parts of it are meant to govern during normal course of things.

In order to reflect on each alternative turn by turn, this is the time of very great uncertainties as to when the pandemic period would end so that it is not constitutional to dissolve the house unless otherwise there is a possibility to hold election within six months period post dissolution subsequently. ${ }^{21}$ Honestly speaking, the legislative intent itself reveals that the issue of dissolution is what is to be done in normal course of things. To this end, it is possible to say this provision of the Constitution is inactive during state of emergency. Additionally, at the time when working from home is advised, house dissolution is wrong from practical point of view to accommodate under the public interest justification. So, for the purpose of addressing the public interest, the house should serve till the next election due to these prevailing pressing factors pragmatically. On the other hand, the subject matters to be entertained are new and novel to the Constitution that they can only be addressed through amendment rather than interpretation as far as constitutional interpretation is concerned. Interpretation is, thus, the worst option and precedent that it is only chosen when the subject matters can be addressed within the whim of the currently prevailing constitutional provisions. However, neither postponement of election and related issues

\footnotetext{
${ }^{20}$ Supra note 3. The Constitution provides non-derogable constitutional provisions and non-derogable rights. Article 1 deals with nomenclature of the state whereas article 25, 18 and 39 (1) (2) which state about equality, freedom against inhuman treatment and torture and right to self-determination up to secession respectively. Understandably, by declaring the right provided under article 39 non-derogable, which is almost equivalent with election in its implementation where referendum may be put in place; election must be excluded deliberately. In other words, the right to elect and to be elected is made derogable a fortiori under the Constitution. Therefore, due to this fact, there is no genuine ground to contest postponement of the election.

${ }^{21}$ Supra note 3 , article 60 (3).
} 
nor extension of parliamentary office term could be within the whim of the provisions of the Constitution. If there is something to do with them, it must be through constitutional amendment. Moreover, in order to request for constitutional interpretation, there must be some discounting factor(s) like silence, unreasonable, ambiguity, vagueness etc within the construction of constitutional provision. In the case at hand, none of the factors is set in to motion. So, the house has no mandate to provide advisory opinion or consultancy service in this regard. ${ }^{22}$ For an amendment to be an option as well, it does not also hold water. The procedure of amendment is almost proximate with conducting full-fledged election that public participation is mandatory as well as intrinsic essential to amend any part of the Constitution under legitimate procedure. ${ }^{23}$ Fearing for an election works validly for an amendment since public voice is meant as the validity procedural ingredient. Otherwise, it results contravening the very purpose of the emergency declaration as well.

Finally, the author of this article believes that continuance with an emergency decree is the lesser evil when compared with the remaining three alternatives. Blatantly speaking, once declared, an emergency decree is supreme in itself during state of emergency. It is applicable alone by setting aside other constitutional provisions except those made non-derogable. On top of this, a factor requiring emergency declaration varies in intensity, nature and/or scope. Some may demand total ban being international issue like the current pandemic. Other may be only national wide or local kind like endemic, war, natural disaster etc. In some cases of emergency condition, conducting elections may be possible partially or wholly according to facts on the ground. In some cases, it is impractical and unrealistic like in the current situation unequivocally. Thus, it is plausible to entertain when and how to conduct election during or post emergency situation under emergency declaration within the purview of article 93 of the Constitution accordingly i.e. being itself prime and grand exigency situation, emergency admits no necessity justification anymore. It does not tolerate and know any superior at the time of its functionality so far as the situation has been intact and once it has been put in to force to govern the siege. For emergency decree, therefore, it is supreme in itself during the time admitted for its operation that supremacy admits no superior rather it will be binding as part and parcel of the Constitution through article 93 in Ethiopia under such exceptional circumstances. Because, the decree only concedes the situation under consideration in detail and its exigency context above ordinary provisions of the Constitution and other subordinate laws exceedingly.

\footnotetext{
${ }^{22}$ FDRE Proclamation No. 251/2001 Constitution of the House of the Federation and the Definition of its Powers and Responsibilities Proclamation, article 4 (2) which read as .... the House shall not be obliged to render a consultancy service on Constitutional interpretation.

${ }^{23}$ Supra note 3, article 104 which states that any proposal for constitutional amendment, if supported by two-thirds majority vote in the House of Peoples' Representatives, or by a two-thirds majority vote in the House of the Federation or when one-third of the State Councils of the member States of the Federation, by a majority vote in each Council have supported it, shall be submitted for discussion and decision to the general public (...).
} 


\section{Concluding Remarks}

A state of emergency is governmental action taken during an extraordinary national crisis that usually entails broad restrictions on human rights in order to resolve the crisis. In theory the restrictions are limited in time; once the crisis has been resolved, the country would return to full respect for universally recognized human rights. In a conflict between survival of the nation and strict enforcement of human rights, international law doctrine supports national survival. In practice, however, restrictions on human rights have been more extreme and longer lasting than necessary for national survival.

International Covenant on Civil and Political Rights also provides for the possibility of derogations (as distinguished from mere limitations of the rights guaranteed) in highly exceptional circumstances (article 4). Derogations are not possible from the so-called absolute rights: the right to life, the prohibition of torture and inhuman or degrading treatment or punishment, and of slavery, and the nullum crimen, nulla poena principle among others. But it does not extend to the right to vote. In Ethiopia, by the same token, the Council of Ministers of the Federal Government has the power to declare a state of emergency when an external invasion or a breakdown of law and order, which endangers the constitutional order and cannot be controlled by the regular law enforcement agencies and personnel, occurs as per the pertinent rule of article 93 (1). So does for a natural disaster, an endemic or an epidemic. Consequently, it is possible to derogate human and democratic rights except for those the "holy cow provisions" i.e. untouchable provisions in any extra ordinary situation provided according to article 93 (4) (C) of the Constitution. It goes without saying that except for those provisions, thus, the remaining constitutional provisions could be set asided for the purpose of common concern and in the due course of implementing the very purpose of emergency declaration. So as there has been no clause making the provisions dealing with the matters under consideration, no dissolution of the House as per article 60 and amendment could be undertaken, done it would be, it goes against the Constitution to render null and void consequently. Besides, there should be some point of determination in relation to emergency decree or the subject matter included thereinunder to initiate Constitution interpretation saving therein the quest of the House referred in the Constitution mutatis mutandis. ${ }^{24}$ If not, interpretation, amendment and dissolution are against the Constitution that neither of them is possible because there is no need to do so since emergency issues should have been covered under 93 by prevailing over article 60 and the remaining Constitutional provisions. The provisions dealing with dissolution of the house, interpretation and amendment have already been deactivated and dysfunctional during state of emergency. Non-derogable provisions are clearly incorporated under the Constitution in black and white including the right to self-determination up to secession. However, there is no similar reserva-

\footnotetext{
${ }^{24}$ Federal Democratic Republic of Ethiopia, Proclamation No. 798/2013, A Proclamation to Re-enact for the Strengthening and Specifying the powers and duties of the council of constitutional inquiry, article 3 (2) (c).
} 
tion for election, which can be understood as the deliberate deed of the legislature and it is out of the legislative intent. Reproaching it, it would be jurisprudential violation to resolve to any of the other options that could result down claiming of the legal system from upper, which would be the worst backsliding since there has been no subtle ground to opt to the other alternatives at all except for continuance under emergency decree and addressing these constitutional issues there under. Concludingly, extension of the office term of HoPR and election period is legitimate and persuasive though the means of extension was wrong. The issues should have been settled under the emergency decree instead of constitutional interpretation. Therefore, it is safe to conclude that the means is wrong while an end is plausible and sound.

\section{Conflicts of Interest}

The author declares no conflicts of interest regarding the publication of this paper.

\section{References}

Ackerman, B. (2006). Before the Next Attack: Preserving Civil Liberties in an Age of Terrorism (p. 446).

African Charter on Democracy, Elections and Governance (2007). http://archive.ipu.org/idd-E/afr_charter.pdf

African Union Declaration on the Principles Governing Democratic Elections in Africa, AHG/Decl.1 (XXXVIII) (2002).

https://www.ohchr.org/EN/Issues/RuleOfLaw/CompilationDemocracy/Pages/AHG.asp $\underline{\mathrm{x}}$

Aoláin, F. N. (2006). Law in Times of Crisis: Emergency Powers in Theory and Practice (pp. 72-110).

Basic Law for the Federal Republic of Germany in the Revised Version Published in the Federal Law Gazette Part III, Classification Number 100-1, as Last Amended by Article 1 of the Act of 28 March 2019 (Federal Law Gazette I, p. 404).

Dyzenhaus, D. (2006). The Constitution of Law: Legality in a Time of Emergency. Cambridge: Cambridge University Press. https://doi.org/10.1017/CBO9780511618246

Ekeland, T. (2005). Suspending Habeas Corpus: Article I, Section 9, Clause 2, or the United States Constitution and the War on Terror. Fordham Law Review, 74, 1475. https://ir.lawnet.fordham.edu/flr/vol74/iss3/11

Election Obligations and Data Base (EOE). https://eos.cartercenter.org/quotes?part $\% 5 \mathrm{~B} \% 5 \mathrm{D}=6$

Ethiopian State of Emergency Proclamation Enacted to Counter and Control the Spread of COVID-19 and Mitigate Its Impact, Proclamation No. 3/2020.

FDRE Proclamation No. 251/2001 Constitution of the House of the Federation and the Definition of Its Powers and Responsibilities Proclamation.

Following the Proclamation No. 3/2020, Regulation Enacted by Council of Ministers Enlisted the Restrictions under Article 3 (1).

https://globalfreedomofexpression.columbia.edu/publications/ethiopian-council-of-mi nisters-regulation-for-the-implementation-of-the-state-of-emergency

ICCPR (1966). Adopted by the UN General Assembly in Resolution 2200 A (XXI) of 16 
December 1966 at New York, Entered into Force on 23 March 1976, Article 25.

Locke, J. (1980). Second Treatise of Government.

Martinez, J. S. (2005). Inherent Executive Power: A Comparative Perspective. Yale Law Journal, 115, 2480-2496. https://doi.org/10.2307/20455703

Posner, E. A., \& Vermeule, A. (2007). Terror in the Balance: Security, Liberty and the Courts.

Schmitt, C. (1976). The Concept of the Political.

Schmitt, C. (1985). Der Hüter der Verfassung.

Schmitt, C. (2005). Political Theology: Four Chapters on the Concept of Sovereignty. Chicago, IL: University of Chicago Press. https://doi.org/10.7208/chicago/9780226738901.001.0001

The Constitution of the Federal Democratic Republic of Ethiopia, Proclamation No. 1/1995, Federal Negarit Gazeta-No.1, 21st August 1995.

Vermeule, A. (2008). Our Schmittian Administrative Law. Harvard Law Review, 122, 1095.

Worldometer.

https://www.worldometers.info/coronavirus/?fbclid=IwAR1acMVd41WdGA4D0FQE mhXtwq6 NJSZCVVjXAuG1n5eryz2We 3KaLtyfA\#countries 